\title{
Why Intellectual Virtues Matter
}

Bernardo N. Caslib, Jr.

\begin{abstract}
Following Linda Zagzebski's pioneering work in virtue epistemology, intellectual virtues have been at the receiving end of great interest in several sectors of the philosophical world. Zagzebski largely thinks that the importation of the concept of virtue, primarily an ethical concept, into epistemology holds the key to problems in epistemology. A challenge to Zagzebski, however, is the question of the innate compatibility of the anatomies of the two realms, ethics and epistemology. Can the concept of virtue be applied to epistemology, too? Is there a real connection between moral and intellectual virtues? This paper attempts at providing a way by which this challenge can be dealt with. By examining Julia Annas' arguments, and the concept of phronesis as a key Aristotelian virtue, this paper forwards the position that there is a huge overlap between intellectual and moral virtues, that contrary to claims of incompatibility, one can even facilitate the attainment of the other, and that the life of truth may after all be the life well lived.
\end{abstract}

Keywords: Aristotle, virtue, intellectual virtues, ethics

\section{Introduction}

$\mathrm{W}$ hat is wisdom, as a virtue? In the Filipino context, wisdom is roughly translated as karunungan. A person who is marunong (or alternatively, madunong) is virtuous because he has a particular insight into the nature of truth and reality. Oftentimes, karunungan is ascribed to the elders who are assumed to be experienced in life (and sometimes, learned too). Karunungan is not something that one can attain through mere schooling, however. It is honed by one who goes through life: confronts problems, celebrates victories, and commits mistakes-someone who has done it all. It is one that is borne out of the different life tours and detours of a person. One who is marunong is deemed discerning. Oftentimes, the marunong may not be understood initially by many, but his pronouncements later on prove to be right and true. This kind of sharp discernment is seen in

(C) 2017 Bernardo N. Caslib, Jr.

https://www.kritike.org/journal/issue 21/caslib december2017.pdf

ISSN 1908-7330 


\section{INTELLECTUAL VIRTUES}

one of Rizal's concocted characters in the novel, Noli Me Tangere: Pilosopo Tasyo. The old man is always misunderstood, and is even considered crazy by his contemporaries. In the end, his extraordinary insight into the nature of things in the society proved to be prophetic. As in the West, karunungan is an intellectual virtue, an example of "acquired character traits that involve appropriate epistemic motivations, appropriate epistemic actions, and reliable success in attaining true beliefs." 1

Moreover, the marunong paves the way for the mabuti. The marunong, owing to his sharp familiarity with reality and truth is most capable of knowing what is right and good. A marunong is expected to also be mabuti. He is expected to be more understanding of those who have not attained (yet) a considerable amount of karunungan. In fraternal conflicts, an elder sibling is expected to be more giving to the younger ones. Cases of inconsistency between karunungan and kabutihan are frowned upon in the Philippine society. ${ }^{2}$ Someone who is deemed marunong but whose actions are considered brash is unacceptable in the Philippine context. This has been demonstrated perpetually by frustrations and disappointments over educated politicians who, after earning multiple degrees in renowned universities around the world, still succumb to corruption. Ideally, the intellectual virtue of being marunong leads all the way up to the moral virtue of being mabuti.

Horiuchi and Yamada convey that in Japanese,

... [i]t takes two words to define wisdom fully: chie and eichie. Chie refers to wisdom as it appears in the sphere of ordinary life, at home or at work. This is not just the fruit of practical experience, important as this may be. It also has a moral dimension, being defined as the 'mental activity that leads us to discern the truth of things and to judge what is right and what is wrong.' And since, in the Japanese worldview, there is no clear distinction between the sacred and the profane, it also has a religious flavor to it. Chie is the first part of the continuum of wisdom that ascends to eichi, which is the 'intelligence which enables men to understand profound

1 Heather D. Battaly, Virtue and Vice (Oxford: Blackwell Publishing Ltd. and Metaphilosophy LLC., 2010), 4.

${ }^{2}$ In hindsight, I suppose Filipinos who are marunong but who are not mabuti are those who do not necessarily know what is right and good. They may be, for the most part, akratic. Akrasia as propounded by Aristotle in the Nicomachean Ethics is weakness of the will. An Akratic person is one who is aware of the moral blunder but whose will is too weak to do what he thinks is right. This may be better dealt with in another exposition.

(C) 2017 Bernardo N. Caslib, Jr.

https://www.kritike.org/journal/issue 21/caslib december2017.pdf

ISSN 1908-7330

(c) $)$ BY-NC-ND 
truth,' and which is the essence of the higher range of existence, such as the ascetic religious life. ${ }^{3}$

In Japanese culture, the connection between the intellectual and the moral life is so intertwined that the intellectual disposition of an individual determines his action as well. Consistent with our own Filipino worldview, our Asian neighbor also sees intellectual virtues as closely intertwined with moral virtues.

In the West, this is also apparent. When Socrates said "know thyself," he was reminding the Athenians that to know oneself is the key to living a moral life. Without proper knowledge of the self, incapable of monitoring the soul, one falls into the pit of moral decay. Bereft of opportunities to nail what virtues are, how can one be expected to do what is right? With his intellectualist ethics, Socrates has been trying to make Athenians reflect and examine their own lives for the purpose of making them stick to lives of virtue and as a consequence, looking after their own souls. He even calls himself a gadfly for constantly getting Athenians on their toes when they seem to be forgetting the road to a life well lived.

So, what is the connection of our intellectual temper and our moral life? What is the connection between moral virtues and intellectual virtues? Are intellectual virtues not facilitative of moral virtues, too?

\section{The Line between Moral and Intellectual Virtues}

Julia Annas affirms what Bloomfield earlier stated4: "Moral virtue is one kind of skill, intellect is another." ${ }^{5}$ Annas is convinced that the two are discrete spheres of excellence that subsuming one under the other is not the best possible way of understanding the relationship between the two. Annas believes that the new approach in epistemology, Virtue Epistemology, espoused by Zagzebski, that utilizes the vocabulary of ethics in epistemology, may not at all be tenable. Referring to intellectual and moral virtues, she cautions that "[n]either should be seen as a sub-kind of the other - although of course any realistic account of the moral life will find many complex connections between them." 6

\footnotetext{
${ }^{3}$ Kazunubu Horiuchi and Jun Yamada, "Wisdom," in Happiness and Virtue Beyond East and West, ed. by K. Ryan, B. Lerner, K. Bohlin, O. Nakayama, S. Mizuno, and K. Horiuchi (Tokyo: Tuttle Publishing, 2011), 133.

4 Paul Bloomfield, "Virtue Epistemology and the Epistemology of Virtue," in Philosophy and Phenomenological Research 60 (2000): 23-43.

${ }^{5}$ Julia Annas, "The Structure of Virtue," in Intellectual Virtue, ed. by M. De Paul and L. Zagzebski (New York: Oxford University press, 2003), 20.

${ }^{6}$ Ibid.
}

(c) 2017 Bernardo N. Caslib, Jr. https://www.kritike.org/journal/issue 21/caslib december2017.pdf ISSN 1908-7330 


\section{INTELLECTUAL VIRTUES}

In a series of contentions, Annas explains why there is no necessary connection between the two. Moral virtues are concerned with practical affairs of life, while intellectual virtues are concerned with truth. The ends of these two fields are essentially different. In her words, "[ $t$ ]he real distinction emerges when we consider that moral virtue is essentially practical; it is the skill of living, where living, in the virtue tradition, is seen as essentially, active, shaping your life so that it is ordered from within." 7

Using the notions of 'virtue as a skill' and 'virtue and success' as fulcrums of analysis, Annas confirms her hesitations with the relationship between the two and sets out to just show why.

For Annas, moral virtues and intellectual virtues, as skills, are distinctive. Their aims "can but need not converge." 8 Annas disagrees with her understanding of Zagzebski ${ }^{9}$ that the latter considers one kind of virtue as a subset of the other: that intellectual virtues are forms of moral virtues. Moral virtue is not a subset of intellectual virtue and definitely, intellectual virtue is not a subset of moral virtue. As a skill, the two are distinct, their aims different. "The real distinction emerges when we consider that moral virtue is essentially practical; it is the skill of living, where living, in the virtue tradition, is seen as essentially active, shaping your life so that it is ordered from within." 10 Intellectual virtues on the other hand, are not practical. The aims of intellectual virtues are theoretical. They are directed at goals other than good action. They are considered with truth, evidence, and justification. Considered from this vantage point, the two are distinct.

Annas adds that "moral virtues essentially involve emotions and feelings in a way not true of the intellectual virtues." Moral virtues such as courage, justice, temperance all entail some appeal to man's affect-a requirement that may not be present in intellectual virtues. While temperance, involves weighing in feelings of desire with other considerations (justice, fairness, etc.), wisdom does not seem to be concerned with any feelings, but only a cognitive operation that approaches truth.

Annas is quick to admit however that "... it would be a mistake to hold that development of an intellectual virtue like perseverance or intellectual honesty never involves such control and transformation of recalcitrant, not purely intellectual, elements of the person."11 Even intellectual virtues, or its employment at least, may involve some feelings on the part of an agent. Drawing the distinction in this light may prove futile.

\footnotetext{
7 Ibid., 21.

8 Ibid., 23.

${ }^{9}$ Cf. Linda Zagzebski, Virtues of the Mind (Cambridge: Cambridge University Press,

${ }^{10}$ Julia Annas, “The Structure of Virtue," 21.

${ }^{11}$ Ibid.
} 1996).

(c) 2017 Bernardo N. Caslib, Jr. https://www.kritike.org/journal/issue 21/caslib december2017.pdf ISSN 1908-7330

(c) $)$ BY-NC-ND 
For Annas, the main difference of the two kinds of virtues, in terms of skill, is this: that moral virtues are practical skills aimed at a practical end: the good life. Intellectual virtues are targeting something else, at achieving truth. Even conceding that intellectual virtues "deepen the understanding which is the basis of the moral virtues," 12 Annas still thinks that the two kinds of virtues are completely distinct sets, not necessitating the other.

For Annas, it would have been better if the two are mutually dependent or are aimed at one and the same thing. She even admits that some intellectual virtues are facilitative of, if not completely necessary for, the attainment of some moral virtues. Phronesis or practical wisdom as a key intellectual virtue, is a requisite in the Aristotelian system of ethics in attaining the mean between two extremes. Only a life lived and sharpened in practical wisdom can locate a mean between two excesses.

Even granting this however, Annas still thinks that cases such as the one mentioned above is an exemption rather than the norm. She even forwards that the search for truth may, in some cases, be antithetical to the search for a good life. Indeed, she thinks that "seeking truth can become an end indifferent to or even conflicting with the end of living according to moral virtue." 13 Citing the "way the 'Guardians' are forced to rule in the central books of the Republic" in Plato's Theaetetus, and Aristotle's 'well-known conflict' between the body of Nicomachean Ethics and the second part of 'Book $10^{\prime}$, Annas claims that the search for truth may sometimes displace the aims of living a good life ${ }^{14}$. Subscription to this position can be a little difficult.

In terms of success, Annas elucidates that, on one hand, intellectual virtues are aimed at targets, immediate goals (truth of a proposition, for example) that may be achieved in discrete, piecemeal fashion. On the other hand, to be successful in achieving moral virtues, one has to experience a full life of mastering a particular virtue (honesty, for example).

Annas identifies two aims in acting of a virtuous person: telos and skopos. Telos is the "overall aim of living virtuously and acting from motives of virtue." 15 In the Aristotelian ethics, the telos is eudaimonia or human flourishing. One requires a lifetime of habit in order to attain a particular virtue. In addition to this, a virtuous person also aims at skopos, or the intermediate goal in any particular case of acting virtuously. The skopos are the little steps that one takes in order to eventually get into the telos. ${ }^{16}$

12 Ibid., 22.

${ }^{13} \mathrm{Ibid}$.

${ }^{14}$ Ibid.

${ }^{15}$ Ibid., 24.

${ }_{16}$ The difference is reminiscent of a scene in Paulo Coelho's novel, The Witch of Portobello. Talking of his character Athena learning the art of calligraphy and the importance of practicing, Coelho puts: "You know the effort it took to sit in the correct position, to quiet your soul, keep your intentions clear, and respect each letter of each word. Meanwhile, keep

(c) 2017 Bernardo N. Caslib, Jr. https://www.kritike.org/journal/issue 21/caslib december2017.pdf ISSN 1908-7330 
Moral virtue requires both skopos and telos. In the analogy, this dual success is manifested in both being able to master calligraphy and succeeding in every individual attempt at writing the words. Contrary to this, intellectual virtues are concerned only with skopos, not with telos. When one attains a truth, one normally says that the knower has attained an intellectual virtue. One need not aim at a universal end or telos (be consistently hitting the truth with the right epistemic motivation) in order to be considered intellectually virtuous. This is the irreconcilability between the two kinds of virtues.

For Annas, the employment of the concept of virtue in epistemology is not just problematic because of the difference in success requirements (skopos vs. telos), but because of the innate nature of the concept of virtue that may not be applicable in the field of epistemology.

I disagree with this understanding of the relationship between moral and intellectual virtues. First, I do not agree with the position that Annas holds about moral and intellectual virtues as skills, and as a consequence, their difference in targets. While Annas holds that truth is the necessary end of intellectual virtues, I forward the position that there might be other possible ends of intellectual virtues. Not all intellectual virtues have truth as its end goal. The ability to draw clear ideas that can eventually transform one's predicament into a better one is surely an epistemic good. Likewise, the possession of insights does not just involve truth; and yet it is considered an epistemic good, especially because some insights can be robust, and therefore, enrich the epistemic agent who holds them. These two examples point to the fact that creativity as an intellectual virtue does not, unlike Annas' claims, target truth as its end.

Having what was laid down considered will bring us to disregard the second argument of Annas: that moral and intellectual virtues are different because the other one requires both skopos and telos while the latter, only telos. Like moral virtues, some intellectual virtues require a lifetime of manifestation in order to be considered present in the epistemic agent. Because the truth of propositions is not necessarily their end goal, their employment in uniform fashion is necessary in order for the epistemic agent who holds them to fully claim that he has them. These epistemic virtues are honesty, open-mindedness, humility and groundedness, intellectual courage, intellectual generosity, creativity, and passionate love for truth. These epistemic virtues are not necessarily attained by getting at their target once

practicing. After a great deal of practice, we no longer think about all the necessary movements we must make; they become part of our existence. Before reaching that stage, however, you must practice and repeat. And if that's not enough, you must practice and repeat some more... The moment will come when you no longer need to think about what you're doing. You become the letter, the ink, the paper, the word." Paulo Coelho, The Witch of Portobello (New York: Harper Collins, 2006), 81-82.

(C) 2017 Bernardo N. Caslib, Jr. https://www.kritike.org/journal/issue 21/caslib december2017.pdf ISSN 1908-7330

(c) BY-NC-ND 
or twice, like skopos. These virtues, like the moral virtues, require consistent display. In addition, some of these epistemic virtues, like the passionate love for truth, may not necessarily attain truth, yet can still be an intellectual virtue. Certainly, the line between intellectual and moral virtues cannot be drawn in a clear-cut fashion.

In the next section, I will try to present another way of understanding the two virtues and their connection by going back to Aristotle's exposition of the intellectual virtues.

\section{Going back to Aristotle}

Consulting Aristotle sheds light onto the discourse by clarifying distinctions. According to him, in analyzing virtues, one can make a distinction between the "virtues of character and other excellence of thought or understanding." 17 The second, he calls the intellectual virtues. All intellectual virtues are aimed at the same thing: truth.

However, there are two kinds of objects of the intellectual virtue. When one concerns himself with the truth of theoretical science, he is dealing with objective truths. A person who seeks truth by validating and checking for the veracity of his scientific findings can then be said to be concerned with this. However, one who is concerned with the truth of his ideals and practical choices can also be considered to be dealing with intellectual virtues. Although the kind of truth that is his object of concern is different, he is after the same goal, truth.

Aristotle adds that "truth is the function of both intellectual parts (of the soul). Therefore, those characteristics which permit each part to be truthful as possible will be the virtues of the two parts." 18 What makes a man able to attain virtue is his capacity to discern and exercise deliberation to hit the mean between extremes. It is practical wisdom that guides man to attain what is morally excellent. Aristotle emphasizes that "practical wisdom is a truthful rational characteristic of acting in matters involving what is good for man."19 Listening to the voice of reason and considering all circumstances before making a decision seems to be the simplest way of understanding this. Importing Aristotle in understanding the wisdom of Confucius, one can understand what Dan mentions: "[e]very one of us has our own goals, but in the hurried, endlessly repeating cycles and rhythms of work, how much time and space do we have to pay attention to our inner heart? The part of ourselves that performs in a social role is plainly visible, but often we muffle

\footnotetext{
${ }^{17}$ Aristotle, Nicomachean Ethics, trans. by Martin Ostwald (Indianapolis: The BobbsMerrill Company, Inc., 1962), 146.

${ }^{18}$ Ibid., 169.

${ }^{19}$ Ibid., 154.
}

(c) 2017 Bernardo N. Caslib, Jr. https://www.kritike.org/journal/issue 21/caslib december2017.pdf ISSN 1908-7330 
the voice of our own spirit." 20 Despite the obvious differences between Confucius and Aristotle, here is one where they seem to agree: what Confucius might have meant by the summon of the heart, in Aristotle, this is the call of one's soul to heed the use of practical reason.

It seems clear then that to Aristotle, the intellectual virtue of practical wisdom is a necessary condition for attaining moral virtues. "There is no virtue without wisdom." ${ }^{21}$ Right action and dispositions are guided by correct reasoning, and right reason is determined by practical wisdom. When one has to decide what action to take, say, in between giving all his money to charity, and not giving at all, one decides after due consideration of past and present experiences. One consults one's priorities and inclinations. What kind of man will this make of me? One communicates with one's inner self and asks what kind of person he wants to become.

To do this, one has to hone one's intellectual virtue of practical wisdom. Aristotle puts it best when he says that "[it] is now clear that we should still need practical wisdom, even if it had no bearing on action, because it is the virtue of a part of our soul. But it is also clear that (it does have an important bearing in action, since) no choice will be right without practical wisdom and virtue." 22 Aristotle's position seems clear: one needs a particular kind of intellectual virtue to become morally virtuous: practical wisdom.

Practical wisdom, phronesis, requires a lifetime of practice in order to be truly present in a person. "To possess practical wisdom, in Aristotle's view, is to be good at thinking about what one should do." 23 To have practical wisdom then, is to have the capacity to think of what one should do in order to attain a fulfilled, eudaimonic life. Phronesis involves understanding, not just attainment of truth. Is the truth of the color of one's socks as valuable as the truth about someone's claim to be a hero? Practical wisdom allows the agent to discriminate. This intellectual virtue, as a representative virtue, almost akin to what we mean in Filipino by karunungan, does not simply concern itself with truth. It puts premium to the quality of deliberation that the epistemic agent has in relation with his life. Indeed, with phronesis, one sees the perfect blending of the moral and the intellectual, and the fact that they cannot be separated. Phronesis seems to act as a manager of possible conflicts between intellectual and moral virtues. 2009), 142.

${ }^{20} \mathrm{Yu}$ Dan, Confucius from the Heart, trans. by E. Tyldesly (Great Britain: Macmillan,

${ }^{21}$ Aristotle, Nicomachean Ethics, 171.

22 Ibid., 171.

${ }^{23}$ Gerard Hughes, Routledge Philosophy Guidebook to Aristotle's Nicomachean Ethics (London and New York: Routledge, 2013), 114.

(c) 2017 Bernardo N. Caslib, Jr.

https://www.kritike.org/journal/issue 21/caslib december2017.pdf

ISSN 1908-7330

(c) $)$ BY-NC-ND 
However, the hanging question remains: how many of the intellectual virtues have the same character and function as practical wisdom? Are all intellectual virtues considered moral virtues? Are they all eventually directed towards the same end as living a moral life?

\section{The Connection between Intellectual and Moral Virtue: An Alternative Way of Looking at It}

Annas is convinced that the idea of intellectual virtues being subsumed to moral virtues or vice versa cannot hold because the anatomies of the two are highly different. I take the Aristotelian position and assert that there is a real relationship between the two virtues.

In terms of extension, some intellectual virtues are necessary in order to attain moral virtues. Some has functions that overlap with each other. The premise here is that moral virtues are deliberated on, and are decided by moral agents. One cannot attain moral virtues by simply going with the flow, acting randomly in every given occasion. This also assumes that actions are motivated by intellectual judgments, and not just emotional biases. Having said this, intellectual virtues such as practical wisdom and with it, corollary virtues such as reflection and deliberation, are necessary to attain moral virtues. Attainment of truth, true virtues in this case, is an imperative in order to attain moral virtues. Without knowing which virtues to hone, one is lost in a sea of tendencies. Attaining excellence and making it a part of one's system are, thus, rendered impossible.

There should be a forthright concession however, that not all intellectual virtues are necessary for moral virtues. Even Aristotle admits this. In summary, having a particular set of intellectual virtues is necessary for moral virtues. Having moral virtues presupposes having some kind of intellectual virtues. Having intellectual virtues however, does not necessarily point to the direction of moral virtues (as in cases of akrasia ${ }^{24}$ ), but it will be odd to think of someone who has attained moral excellence without having intended such.

Moreover, some intellectual virtues, because of their close affinity to moral virtues, run parallel to intellectual virtues, which means that they may move towards the same object. Some intellectual virtues lead us to moral virtues, whether incidentally or otherwise. A paradigmatic case in point is the virtue of open-mindedness. In the Problems of Philosophy, Bertrand Russell claims that a man who has been trained in the ways of philosophy, incidentally, also enlarges his not-self-that aspect of existence that does not belong to him. By allowing for possibilities, a man of philosophy becomes a

${ }^{24}$ One knows what is right, but does not follow the dictates of such reason.

(c) 2017 Bernardo N. Caslib, Jr.

https://www.kritike.org/journal/issue 21/caslib december2017.pdf

ISSN 1908-7330

(cc) BY-NC-ND 
yes man who simply concedes to what the universe brings him on his plate, no matter how seemingly impossible they are. ${ }^{25}$ This kind of openness, in turn, enlarges him, his self and turns his perspective $360^{\circ}$.

This openness to possibilities, which is intellectual, translates into action, according to Russell. A man who has been conditioned to be open to everything that comes his way becomes open not just to ideas but even to the people he meets along the way. An intellectually open-minded person therefore, is also a morally open, tolerant, ethical agent.

It is also difficult to conceive of intellectual virtues to be moving against the direction of the good. When Aristotle opens the Nicomachean Ethics with "Every art or applied science and every systematic investigation, and similarly every action and choice, seem to aim at some good; the good, therefore, has been well defined as that at which all things aim," ${ }^{26}$ he includes truth as a possible good. If every science or investigation is aimed at some good, is not that good the truth? If this reading is correct, then do intellectual virtues not run parallel to the moral virtues whose end is the good for the moral life?

There is another contrary position to Annas' that one could take in relation to virtue ethics. Truth need not be attained, as the skopos, in order for the agent to be considered intellectually virtuous. In the same manner that an agent could be considered morally virtuous simply because of the moral motivational component present, he may also be called intellectually virtuous owing to his having the right intellectual motivational component. "What makes intellectual virtues intellectual is that they (or most of them) include motive dispositions connected with the motive to get truth, and reliability is entailed by the success component of the virtue." ${ }^{27}$ Hence, a person could be considered intellectually virtuous, not necessarily because of the attainment of truth, but because he possesses the motives and dispositions attached to intellectual virtue. An honest man may at a time, declare something untrue, not because he wanted to, but because truth was most carefully hidden from him. This man may still be considered intellectually virtuous. Indeed, "attaining good ends is not enough (or not even required) for virtue, since one can attain good ends, and even perform appropriate actions, but have vicious motives" ${ }^{28}$ Hence, intellectual virtue is akin to moral virtue.

Annas' sentiment that moral and intellectual virtues are, indeed, two different kinds of virtues. However, the difference in their structures do not

\footnotetext{
${ }^{25}$ Bertrand Russell, The Problems of Philosophy (New York: Hery Holt and Company, 1912). 274.

${ }_{26}$ Aristotle, Nicomachean Ethics, 3.

${ }_{27}$ Abrol Fairweather and Linda Zagzebski, eds., Virtue Epistemology (Oxford: Oxford University Press, 2001), 5.

${ }^{28}$ Heather D. Battaly, Virtue and Vice, 4.

(C) 2017 Bernardo N. Caslib, Jr.

https://www.kritike.org/journal/issue 21/caslib december2017.pdf

ISSN 1908-7330
}

(c) BY-NC-ND 
deny the innate relationship between the two. Given the significant overlaps between them, and the success of the current campaign to see knowledge in terms of virtuous knowers, one should rethink huge contentions like Annas'.

The word that we use in Filipino for wise, 'marunong' is a rich word as it connotes the intimate interplay between the intellectual virtue of wisdom and the moral virtue, goodness. The word presents virtue as holistic, not fragmented. It reminds us that it might be difficult to separate the good life from the life of truth because a good life, for the most part, is grounded on truth. Annas rightfully cautions us not to immediately jump into the bandwagon of using and appropriating virtue ethics into epistemology; but the blurring of lines that she makes in the process of cautioning us might be another object of caution to us, for after all, the similarity between intellectual and moral virtues-as probably detected by Zagzebski-outweighs the differences.

Department of Philosophy, Ateneo de Manila University, Philippines

\section{References}

Annas, Julia, "The Structure of Virtue," in Intellectual Virtue, ed. by M. De Paul and L. Zagzebski (New York: Oxford University press, 2003).

Aristotle, Nicomachean Ethics, trans. by Martin Ostwald (Indianapolis: The Bobbs-Merrill Company, Inc., 1962).

Battaly, Heather D., Virtue and Vice (Oxford: Blackwell Publishing Ltd. and Metaphilosophy LLC., 2010).

Bloomfield, Paul, "Virtue Epistemology and the Epistemology of Virtue," in Philosophy and Phenomenological Research 60 (2000).

Coelho, Paulo, The Witch of Portobello (New York: Harper Collins, 2006).

Fairweather, Abrol and Linda Zagzebski, eds., Virtue Epistemology (Oxford: Oxford University Press, 2001).

Horiuchi, Kazunubu and Jun Yamada, "Wisdom," in Happiness and Virtue Beyond East and West, ed. by K. Ryan, B. Lerner, K. Bohlin, O. Nakayama, S. Mizuno, and K. Horiuchi (Tokyo: Tuttle Publishing, 2011).

Hughes, Gerard, Routledge Philosophy Guidebook to Aristotle's Nicomachean Ethics (London and New York: Routledge, 2013)

Russell, Bertrand, The Problems of Philosophy (New York: Hery Holt and Company, 1912).

Yu Dan, Confucius from the Heart, trans. by E. Tyldesly (Great Britain: Macmillan, 2009)

Zagzebski, Linda, Virtues of the Mind (Cambridge: Cambridge University Press, 1996).

(c) 2017 Bernardo N. Caslib, Jr. https://www.kritike.org/journal/issue 21/caslib december2017.pdf

ISSN 1908-7330 